\title{
The Effect of Work Life Balance on Employee Job Satisfaction among Non Executives in the Public Banking Sector in Colombo District
}

\author{
Arunika, MMA and Kottawatta, $\mathrm{H}$
}

\begin{abstract}
Area of the Study

This study is mainly focused on discussing the effect of work life balance on job satisfaction among non executives in the public banking sector in Colombo district.

\section{Problem of the Study}

The research problem addressed under this study is to investigate what extent work life balance affects on job satisfaction among non executives in public banking sector in Colombo district.

Method of the Study

The data for the present study was collected from 224 respondents in public banks in Colombo by administrating a structured questionnaire, which consisted of 36 statements with 5 point Likert scale. The data analysis included the univariate, bivariate and multivariate analysis method conducted using SPSS (version 16.0).
\end{abstract}

\section{Findings of the Study}

The results of the study emphasize that there was a negative relation of work life balance with job satisfaction and 78.9\% of job satisfaction was explained by work life balance (sig0.000). Except job autonomy, work to family interference, family to work interference, work stress, life stress and work load were negatively correlated with job satisfaction. $82.7 \%$ of job satisfaction was explained by the total variables of work life balance of the model according to multiple regression analysis.

\section{Conclusion of the Study}

It is concluded that there was negative relationship between work life balance and job satisfaction of the non executives in the public banking sector in Colombo district. The bank management has to introduce various strategies to reduce the conflicts of work life of non executives for the purpose of getting maximum contribution.

Keywords: Work Life Balance, Work/Life Stress, Work Load, Job Autonomy

\section{Introduction}

Human Resource Management can be considered as one of the most vital functional areas of management and a source to achieve sustainable competitive advantage for an organization (Opatha, 2009). Therefore every organization is very keen to utilize its human resource in an efficient and effective manner to achieve the intended goals and objectives (Opatha 2009). Research on work life balance and job satisfaction has become a research area of much importance in today's context. This study is an attempt to enhance the existing body of knowledge regarding the above mentioned area with a Sri Lankan approach. 
In recent years, there has been a growing concern about achieving a good balance between work and non-work commitments. The literature has noted the importance of work-life balance, moreover among single parents, working women, dual-career couples and fathers heavily involved in parenting (De Luis Carnicer et al. 2004, cited in Pasamar \& Cabrera 2013).

The concept represents a new approach to human resource management policies intended to encourage the creation of a substantial balance between employees, working and private life. As a result, work life balance is a requirement that actually covers all categories of workers, regardless of gender, age or employment status.

Job satisfaction can also be seen within the broader context of the range of issues which affect an individual's experience of work, or their quality of working life. Job satisfaction can be understood in terms of its relationships with other key factors, such as general well-being, stress at work, control at work, home-work interface, and working conditions. The level of employees' job satisfaction increases by many factors and when employees are satisfied with their work, they feel motivated (Noor 2011).

\section{Problem Background and Problem of the Study}

In the developed counties, there are considerable research works on work life balance and employee satisfaction (Shujat et al. 2011). The situation of the developing countries is starting to pay attention on this front to increase employee job satisfaction (Shujat et al. 2011). In Sri Lanka, the banking sector has evolved considerably. Banks are very competitive and this has resulted in coming up with measures geared towards attracting new customers and retaining the existing ones in order to have a larger market share. Public banks in Sri Lanka also are new bringing in more profits by being customer focused. In order to attain this they have increased their opening hours, introduced more products, opened up more branches and have adopted the latest Information Technology infrastructure. This has led to their employees working longer hours, having a greater and more complex work load, therefore, experiencing a lot of work pressure and creating a culture of poor work life balance resulting to their employees becoming highly dissatisfied with their jobs.

There is an acute shortage of empirical knowledge with regard to the effect of work life balance on job satisfaction of non executives in the public bank sector. Therefore the research problem addressed under this study is to investigate "Does work life balance effect on job satisfaction of non executives in public banking sector in Colombo District in Sri Lanka?"

\section{Research Framework}

Work Life Balance: A study was conducted by Maren and others (2013) to analyze work life balance and job satisfaction among teachers which exposed a negative relationship between work-life conflicts and job satisfaction. Shujat and others (2011) found out that there was a positive relation of work life balance programs on employee job satisfaction. Malik and others (2010) examined a relationship of work life balance/ work life conflict and job satisfaction in a sample of MBBS doctors in Pakistan and revealed that there was no 
significant effect of work life balance on job satisfaction. Rania and others (2011) analyzed the relationship between employee satisfaction and work/life balance and made a contribution to join two distinct research streams, namely employee satisfaction, and work/life balance. Findings suggest that high correlation exists between work task and employee satisfaction with a mediator variable namely work-life balance. Yadav and Dabhade (2014) revealed work life balance was an important determinant of intrinsic aspects of job satisfaction. It was found that employees are more committed towards their job to get higher reward and appreciation. This attitude towards their jobs however increased family conflict but increases job satisfaction. Gomez et al. (2010) highlighted that there is a positive effect of work life balance on job satisfaction of workers. The study done by Nadeem and Abbas (2009) revealed that there was a negative relationship between work to family interference, family to work interference, work load and stress with job satisfaction of Pakistani employees. Taking the sample of university teachers, Arif and Farooqi (2014) concluded their findings as there was a positive relationship between life balance and job satisfaction. As Saif et al. (2011), there was a positive relationship between job satisfaction and work life balance on the results of regression analysis. However, the results of ANOVA implied that there was no significant difference between work life balance and job satisfaction among the top, middle and first line managers. Most of the studies according to the role theory stressed the negative relationship between work life balance with job satisfaction (Adams et al. 1996; Netemeyer et al. 1996). Based on the arguments and empirical evidence the first hypothesis of this study was developed as:

$\mathrm{H}_{1}$ : There is a negative effect of work life balance and employee job satisfaction.

Work - Family Interference: As Greenhaus and Beutell in 1985, work-family interference is a state of affairs where the work and family domains interfere with one other (Kafetsios 2007, p. 15). According to Kafetsios (2007), work life conflict may be either positively or negatively affect to the psychological aspects of worker. There are two aspects of work life balance when considering the interferences between work and life. Work interferes to the family is one aspect and other is that family interferes to the works of workers (Gutek et al. 1991).

Work to Family Interference: Work to family interference is recorded as a negative relationship (Nadeem \& Abbas 2009). As Oswald in 2002, household responsibilities were over-involved by the job related responsibilities. As indicated by Ezra and Deckman (1991), Jayaweera (2005), Cabrita and Heloisa (2006); Janasz and Behson (2007) and Nadeem and Abbas (2009), there is negative effect of the work to family interference. Carlson, Grzywacz and Kacmar (2010), Carly, Allen and Spector (2002) and Netemeyer, Boles and McMurrian (1996) pointed out that there was negative relationship between work to family conflict with job satisfaction. Then, the second hypothesis was developed as:

$\mathrm{H}_{2}$ : There is a negative effect of work to family interference on employee job satisfaction.

Family to Work Interference: The second aspect of work life balance is family to work interference. There are different life matters which directly and indirectly affect to the works of employees. As Nadeem and Abbas (2009), family problems like child care or elderly care 
may be a family matters which interfere with work. As Narayana and Savarimuthu (2014), there was negative relationship between families to work interference with job satisfaction of women working in IT industry in Bengaluru. Carlson, Grzywacz and Kacmar (2010), Carly, Allen and Spector (2002) and Netemeyer, Boles and McMurrian (1996) pointed out that there was negative relationship between family to work conflict with job satisfaction. According to the available research findings, the third hypothesis was proposed as:

$\mathrm{H}_{3}$ : There is a negative effect of family to work interference on employee job satisfaction.

Stress (Family related Stress and Work Related Stress): There are different studies pointed out that there were significant relationship between work family conflict with job stress (Bedeian et al. 1988; Netemeyer et al 2004; Allen et al 2000; Aryee 1992; Kossesk \& Ozeki 1998). Job stress on the topic of work life balance consists of two directions, family related stress and work related stress. As Bedeian et al. (1988), Lopopolo (2002), Netemeyer et al. (2004), there was negative relationship between job stresses on job satisfaction. Hart in 1999 found strong negative relationship between non job stressors and non-work satisfaction. Lu in 1995 pointed out that life stress of Chinese participant on life satisfaction was negatively correlated. This was confirmed by Chang and Sanna in 2003. The fourth and fifth hypotheses were developed based on the research findings as:

$\mathrm{H}_{4}$ : There is a negative effect between family related stress and job Satisfaction.

$\mathrm{H}_{5}$ : There is a negative effect between work related stress and job Satisfaction.

Work Load: Workload is two forms: Physical and mental (Kawada et al. 2010). Moderate staff satisfaction with amount of variety in job was found by Houston et al in 2006. A negative relationship with job overloads and job satisfaction was found by Altaf and Awan in 2011 of their study. Shujat et al. (2011) pointed out through their study that work pressure had negative and weak relation with employees' job satisfaction. Awang and Ahmad (2010) pointed out through a study of academic staff in UiTM Kelantan that there was lack of significant among workload and job satisfaction. However, Chimanika et al (2007) found that high volume of workload leaded low job satisfaction among academic staff members. Hence, the sixth hypothesis of this study was formulated as:

$\mathrm{H}_{6}$ : There is a negative effect of work pressure/work load on employee job Satisfaction.

Job Autonomy: Job autonomy is one of the core dimensions of job characteristic model. Job autonomy was found as the greatest effect on job satisfaction of employee by Loher et al in 1985. However, the moderate effect of job autonomy on job satisfaction was found by Morris and Venkatesh in 2010. DeCarlo and Agarwel (1999), Finn (2001), Liu et al. (2005), Nguyen et al. (2003), Thompson and Prottas (2005), and Wang and Netemeyer (2002) concluded that there was a positive effect of job autonomy on job satisfaction of employee. The seventh hypothesis of this study was formulated as:

$\mathrm{H}_{7}$ : There is a positive effect of job autonomy on employee job Satisfaction.

Relevant research framework of this study is shown in Figure 1. Dependent variable of job satisfaction is influenced by work life balance (independent variable). Work family balance consists of six sub variables such as work to family interference, family to work interference, 
work stress, family stress, work load and job autonomy. The work life balance was measured by the dimensions given by Nadeem and Abbas (2009).

Figure 1: The Relationship between Dependent Variable and Independent Variables

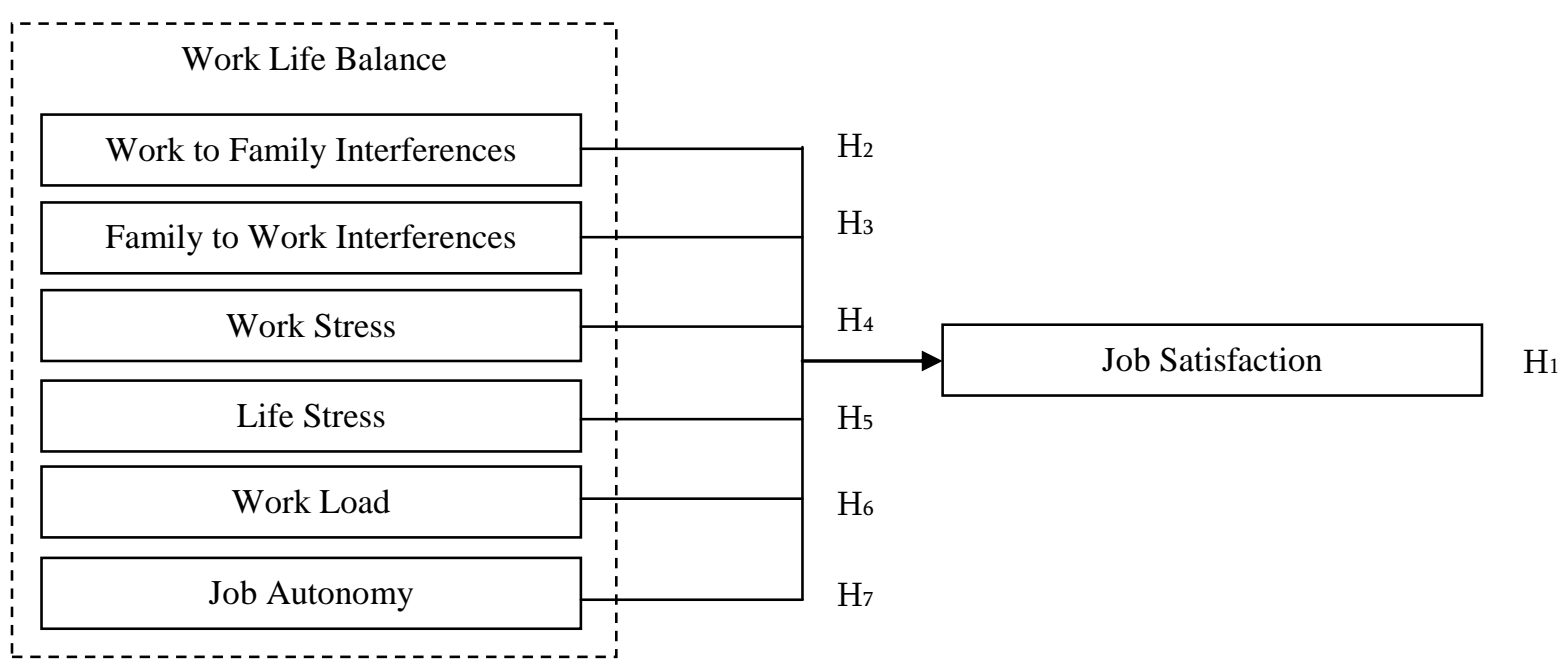

\section{Methods}

\section{Study Design}

The objective of this study was to examine the effect of work life balance on non executive employees' job satisfaction and to identify which factors of work life balance have more influence on employee job satisfaction in public banking sector. Therefore the type of investigation of the study was analytical. The study was done in the natural environment where work proceeded normally. Then, the study can be considered as a field study. None of the variables were controlled or manipulated. Hence the study was a non contrived study; no any artificial or contrived setting was created for the study. The self administered-structured questionnaire was selected as the method of data collection in this study. This study was purely based on primary data. The non contrived field-setting environment was used to collect the primary data.

The survey was carried out among the sample of 224 non executives who worked in the public banks in Colombo district. The sample method of the survey was simple random sampling. In this study, $56 \%$ of non executives were females, while $44 \%$ were males. The age group with highest representation was 31-45 years. It took $43 \%$ of the selected sample. Furthermore, $60 \%$ were married and $40 \%$ were single and $49 \%$ of non executives have professional education and also $50 \%$ of non executives in selected sample have less than 5 year service period.

\section{Measures}

The independents and dependent variable were measured using structured questionnaire with five point Likert-type scales which were completed by the respondents themselves approximately as they have experienced. The level of measurement of both variables would be interval. Work to family interference, family to work interference, work stress, life stress, and work load were measured using 1-5 scale (1-strongly negative and 5-strongly positive). 
Measurements of job autonomy and job satisfaction also were measured using 1-5 scale (1strongly negative and 5-strongly positive). The consistency reliability was examined with Cronbach's Alpha test for all variables i.e. job satisfaction, work to family interference, family to work interference, work stress, family stress, work load and job autonomy were accepted as the alpha value were above 0.72. It suggested that each instrument is at a satisfactory level.

\section{Techniques of Data Analysis}

The primary data collected from the sample were analyzed using the computer based statistical data analysis package, SPSS (version 16.0) for validity, reliability, and relationship testing. The data analysis included univariate, bivariate and multivariate analyses.

\section{Results}

Mean value of the work life balance of the sample is 2.6542 and it indicates that work life balance of the sample respondents were negative. However, job satisfaction of the sample respondents, as table 01, recorded as average (mean value-3.3143, SD-1.05244).

Table 01: Univariate Analysis

\begin{tabular}{|l|c|c|c|c|}
\hline & Mean & $\begin{array}{c}\text { Stand. } \\
\text { Deviation }\end{array}$ & Skewness & Kurtosis \\
\hline Work to family interference & 2.4300 & 0.79014 & -0.016 & -0.474 \\
\hline Family to work interference & 2.7000 & 0.93020 & -0.110 & -1.745 \\
\hline Work stress & 2.5000 & 0.97498 & 0.300 & -1.540 \\
\hline Life stress & 2.7000 & 0.71655 & -0.214 & -1.586 \\
\hline Work load & 2.7200 & 0.81924 & -0.242 & -1.441 \\
\hline Job autonomy & 2.8250 & 0.48954 & 0.266 & -0.580 \\
\hline Work life balance & 2.6542 & 0.64844 & 0.083 & -1.460 \\
\hline Job satisfaction & 3.3143 & 1.05244 & -0.415 & -1.411 \\
\hline
\end{tabular}

The correlation between work life balance and job satisfaction of the sample is given in Table 02 .

Table 02: The Pearson's Correlation between Independent Variables and Dependent Variable

\begin{tabular}{|l|r|r|r|}
\hline & $\mathrm{N}$ & Pearson Correlation & Sig. (1-tailed) \\
\hline Work to family interference and job satisfaction & 224 & -.797 & .000 \\
\hline Family to work interference with job satisfaction & 224 & -.874 & .000 \\
\hline Work stress and job satisfaction & 224 & -.891 & .000 \\
\hline Life stress and job satisfaction & 224 & -.759 & .000 \\
\hline Workload and job satisfaction & 224 & -.815 & .000 \\
\hline Job autonomy and job satisfaction & 224 & .248 & .291 \\
\hline Work life balance and job satisfaction & 224 & -.888 & .000 \\
\hline
\end{tabular}

Correlation coefficient between work life balance and job satisfaction of the sample respondents is -0.888 (sig: 0.000). It implies that there is a strong negative relationship between work life balance and job satisfaction of the workers. Relationship between job autonomy and job satisfaction of the sample is 0.291 and it is not statistically significance 
(sig: 0.291). However, other dimensions of work life balance, work to family interference, family to work interference, work stress, life stress and work load with job satisfaction are negatively correlated and all are statistically significance.

The simple regression analysis of the independent variables with dependent variable is given in Table 03.

Table 03: Results of Simple Regression Analysis between Independent Variables and Dependent Variable

\begin{tabular}{|l|r|r|r|r|r|r|r|}
\hline & \multicolumn{1}{|c|}{$\begin{array}{c}\text { JS with } \\
\text { W/F I }\end{array}$} & $\begin{array}{c}\text { JS with } \\
\text { F/W I }\end{array}$ & \multicolumn{1}{c|}{$\begin{array}{c}\text { JS with } \\
\text { WS }\end{array}$} & $\begin{array}{c}\text { JS with } \\
\text { LS }\end{array}$ & $\begin{array}{c}\text { JS with } \\
\text { WL }\end{array}$ & \multicolumn{1}{c|}{ JS with } & \multicolumn{1}{c|}{$\begin{array}{c}\text { JS with } \\
\text { WLB }\end{array}$} \\
\hline R square & .635 & .764 & .793 & .576 & .665 & .062 & .789 \\
\hline Adjusted R square & .615 & .751 & .782 & .553 & .646 & .010 & .778 \\
\hline F & 31.290 & 58.241 & 68.980 & 24.470 & 35.656 & 1.182 & 67.432 \\
\hline Significance & .000 & .000 & .000 & .000 & .000 & .291 & .000 \\
\hline B - constant & 5.893 & 5.984 & 5.766 & 6.324 & 6.163 & 1.778 & 7.201 \\
\hline B - value & -.797 & -.874 & -.891 & -.759 & -.815 & .248 & -.888 \\
\hline
\end{tabular}

In reference to Table 3, 78.9\% of the variance of job satisfaction is explained by work life balance of the sample. $63.5 \%$ of job satisfaction is explained by work to family interference and $76.4 \%$ of the variance is explained by family to work interference. $79.3 \%$ and $57.6 \%$ of the variance of job satisfaction are explained by work stress and life stress in that order. $66.5 \%$ of variance of job satisfaction is explained by work load and $6.2 \%$ of variance of job satisfaction is explained by job autonomy. However, variance explained by job autonomy is not statistically significant.

Multiple regression analysis of the model is given in Table 4.

Table 4: Multiple Regression Analysis of the Model

\begin{tabular}{|l|c|c|c|c|c|c|c|c|c|c|}
\hline $\begin{array}{l}\mathrm{R} \\
\text { square }\end{array}$ & $\begin{array}{c}\text { Adjusted } \\
\text { R square }\end{array}$ & $\mathrm{F}$ & Significance & $\begin{array}{c}\mathrm{B}- \\
\text { constant }\end{array}$ & $\mathrm{B}_{1}$ & $\mathrm{~B}_{2}$ & $\mathrm{~B}_{3}$ & $\mathrm{~B}_{4}$ & $\mathrm{~B}_{5}$ & $\mathrm{~B}_{6}$ \\
\hline .827 & .747 & 10.372 & .000 & 6.031 & -.167 & -.636 & -.682 & -.047 & .540 & -.070 \\
\hline
\end{tabular}

As Table 4, 82.7\% of variance of job satisfaction is explained by the all variables of the work life balance and it is statistically significant.

\section{Discussion and Conclusion}

Bivariate and multivariate analysis of the sample data reveal that there is a negative relationship between job satisfaction and work life balance of the non executives of the public banks in Colombo district. Correlation coefficient between these two variables is -0.888 and $78.9 \%$ of variance of job satisfaction is explained by work life balance. In reference to mulitiple R square, $82.7 \%$ of variance of job satisfaction is explained work life balance. There are many research findings that can be used to validate the finding of this study. Maren et al (2013), Shujat et al (2011), Adams et al (1996), and Netemeyer et al. (1996) pointed out the negative relationship between work life balance and job satisfaction. However, this major 
finding is contradictory with regard to the study findings of Gomez et al. (2010), Arif and Farooqi (2014) and Saif et al (2011). Therefore, the hypothesis of the study is accepted.

As the finding of the study, there is negative relationship between work to family interference and job satisfaction of the non executives in the public banking sector in Colombo district. The correlation coefficient between these two variables is -0.797 (sig: 0.000 ). $63.5 \%$ of variance of the job satisfaction is explained by the work to family interference and it is statistically significant (F: 31.290, Sig: 0.000). The studies done by Nadeem and Abbas (2009), Ezra and Deckman (1991), Jayaweera (2005), Carlson, Grzywacz and Kacmar (2010), Carly, Allen and Spector (2002) and Natemeyer, Boles and McMurrian (1996) fund the negative relationship between work to family interference and job satisfaction. The study finding is confirmed by the studies done by above researcher. Therefore, the hypothesis is accepted.

Family to work interference and job satisfaction of the non executives in banking sector is recorded as negative relationship. Correlation coefficient between these two variables is 0.874 at 0.000 significant level. $76.4 \%$ of the variance of job satisfaction is explained by the family to work interference and it is statistically significant. This finding can be verified the findings of Carlson, Grzywacz and Kacmar (2010), Carly, Allen and Spector (2002) and Natemeyer, Boles and McMurrian (2006).

Work stress, which are relating to the work places, and job satisfaction of the non executives in the Colombo district banks has been concluded as negative relationship according to the correlation (r: -0.891, sig: 0.000). $79.3 \%$ of variance of job satisfaction is explained by the work stress of non executives in the banks. Life stress and job satisfaction of non executives in the public banks stayed at negative relationship. Correlation coefficient between two variables is -0.759 (sig: 0.000 ) and $57.6 \%$ of variance of job satisfaction is explained by it. Work stress is critical factor to determine the job satisfaction of employee. Bedeian et al. (1988), Lopopolo (2002), Netemeyer et al. (2004), Lu (1995) and Chang and Sanna (2003) pointed out the negative relationship between stress and job satisfaction through their studies.

The relationship between work load and job satisfaction of non executives in the public banks is recorded as negative relationship. Correlation coefficient of two variables is -0.815 (sig: 0.000 ) and $66.5 \%$ of variance of job satisfaction is explained by work load. The findings given by Altaf and Awan (2011), Shujat et al. (2011) and Chimanika et al. (2007) are confirmed by the finding of this study. There is no statistical significance between job autonomy and job satisfaction of the non executives in the public bank.

For the maximum contribution of workers to achieve the bank objectives, management has to introduce appropriate strategies to balance the work and life of workers. Specially considering the work and family matters, stress level and work load of the workers.

Further research studies should consider alternative methods, such as a longitudinal study among non executives instead of cross sectional survey design to measure these variables. 
However, this model is relatively small, and did not take in to consideration other factors that might have affected the relationships between these variables. Therefore further comprehensive examinations should be conducted on other potential mediating or moderating variables influence work life balance and job satisfaction.

\section{References}

i. Adams, AG, King, LA \& King, DW 1996, 'Relationships of job and family involvement, family social support, and work-family conflict with job and life satisfaction', Journal of Applied Psychology, Vol. 4, No. 4, pp. 411-420.

ii. Allen, TD, Herst, DEL, Bruck, CS \& Sutton, M 2000, 'Consequences associated with work-to-family conflict: A review and agenda for future research', Journal of Occupational Health Psychology, No.5, pp. 278-308.

iii. Altaf, A \& Awan, M 2011, 'Moderating Affect of Workplace Spirituality on the Relationship of Job Overload and Job Satisfaction', Journal of Business Ethics, Vol. 104, No. 1, pp. 93-99. http://dx.doi.org/10.1007/s10551-011-0891-0

iv. Arif, B \& Farooqi, YA 2014, 'Impact of work life balance on job satisfaction and organizational commitment among university teachers: A case study of University of Gujrat, Pakistan, International Journal of Multidisciplinary Sciences and Engineering, Vol. 5, No. 9, pp. 24-29.

v. Aryee, S 1992, 'Antecedents and outcomes of work-family conflict among married professional women: evidence from Singapore', Human Relations, No. 45, pp. 813838.

vi. Awang, z \& Ahmed, JH 2010, 'Modelling Job Satisfaction and Work Commitment among Lecturers: A Case of UiTM Kelantan', Journal of Statistical Modeling and analysis, Vol. 1, No. 2, pp. 45-59.

vii. Bedeian, AG, Burke, BG \& Moffett, RG 1988, 'Outcomes of work-family conflict among married male and female professionals', Journal of Management, No. 14, pp. $475-492$.

viii. Cabrita J \& Perista H 2006, 'Measuring Job Satisfaction in Surveys - Comparative Analytical Report', European Foundation for the Improvement of Living and Working Conditions (ef0671).

ix. Carlson, DS, Grzywacz, JG \& Kacmar, KM 2010, 'The relationship of Schedule flexibility and outcomes via the work-family interface', Journal of Managerial Psychology, Vol. 25, No. 4, pp. 330-355.

x. Carly, BS, Allen, TD \& Spector PE 2002, 'The relation between work-family conflict and job satisfaction: A finer grained analysis', Journal of Vocational Behaviour, Vol. 60, No. 3, pp. 336-353.

xi. Chang, EC \& Sanna, LJ 2003, 'Optimism, accumulated life stress, and psychological and physical adjustment: Is it always adaptive to expect the best?', Journal of Social and Clinical Psychology, No. 22, pp. 97-115.

xii. Chimanikire, P, Mutandwa, E, Gadzirayi, CT, Muzondo, N \& Mutandwa, B 2007, 'Factors Affecting Job Satisfaction Among Academic Professionals in Tertiary Institutions in Zimbabwe', African Journal of Business Management, Vol. 1, No. 6, pp. 166-175. 
xiii. DeCarlo, TE \& Agarwal, S (1999). Influence of Managerial Behaviors and Job Autonomy on Job Satisfaction of Industrial Salespersons. Industrial Marketing Management. Vol. 28, pg. 51-62.

xiv. Finn, CP 2001, 'Autonomy: an important component for nurses' job satisfaction', International Journal of Nursing Studies, Vol. 38, pg. 349-357

xv. Gomez, SF, Khan, N, Malik, MI \& Saif, MI 2010, 'Empirically Testing the Relationship of Social Support, Job Satisfaction and Work Family Balance in Pakistani Socio Cultural Set - Up', OIDA International Journal of Sustainable Development, Vol. 2,1, No. 1, pp. 31-37.

xvi. Gutek BA, Searle S, \& Klepa L 1991, 'Rational versus gender role explanations for work-family conflict', Journal of Applied Psychology. Vol. 76, No. 4, pp. 560-568.

xvii. Hart, P 1999, 'Predicting employee life satisfaction: A coherent model of personality, work and non work experiences, and domain satisfactions', Journal of Applied Psychology, No. 84, pp. 564- 584.

xviii. Houston, D, Meyer, LH \& Paewai, S 2006, 'Academic Staff Workloads and Job Satisfaction: Expectations and values in academe', Journal of Higher Education Policy \& Management, Vol. 28, No. 1, pp. 17-30. http://dx.doi.org/10.1080/13600800500283734

xix. Janasz, SC de and Behson, SJ 2007, 'Cognitive capacity for processing work-family conflict: an initial examination', Career Development International.

xx. Jayaweera, AT 2005, 'Management development: A model of linkages between workfamily conflict, job satisfaction and individual's passionate desire to develop through management development opportunities', University of Kelaniya Sri Lanka.

xxi. Kafetsios, K 2007, 'Work-family conflict and its relationship with job satisfaction and psychological distress: The role of affect at work and gender', Hellenic Journal of Psychology, No. 4, pp. 15-35.

xxii. Kawada, T, Ueda, H, Hayashi, M, Sakamoto, A, Uchida, K, Shirato, T \& Etoh, R 2010, 'Relationship among workload, health complaints, and depressive state of workers as revealed using a questionnaire survey', Work, No. 37, pp. 333-339.

xxiii. Kossek, EE \& Ozeki, C 1998, 'Work-family conflict, policies, and job-life satisfaction relationship: A review and directions of organizational behavior human resources research', Journal of Applied Psychology, No. 83, pp. 139-149.

xxiv. Liu, C, Spector, PE \& Jex, S 2005, 'The relation of job control with job strains: A comparison of multiple data sources', Journal of Occupational and Organizational Psychology, Vol. 78, pp. 325-336.

xxv. Loher, BT, Noe, RA, Moeller, NL \& Fitzgerald, MP 1985, 'A meta-analysis of the relation of job characteristics to job satisfaction', Journal of Applied Psychology, Vol. 70, pp. 280-289.

xxvi. Lopopolo, RB 2002, 'The relationship of role-related variables to job satisfaction and commitment to the organizations in the restructured hospital environment', Physical Therapy, Vol. 82, pp. 984-1000.

xxvii. Lu, L 1995, 'The relationship between subjective well-being and psychosocial variables in Taiwan', The Journal of Social Psychology, Vol. 135, pp. 351-359. 
xxviii. Malik, MI, Gomez, SF, Ahmad, M \& Saif, MI 2010, 'Examining the relationship of Work life Balance, Job satisfaction and Turnover in Pakistan', International Journal Sustainable development, vol. 2, no. 1, p. 27.

xxix. Maren, R, Pitarelli, F \& Cangiano, F 2013, 'Work-life balance and job satisfaction among teachers', Interdisciplinary Journal of Family Studies, Vol. 18, pp. 51-72.

xxx. Morris, MG \& Venkatesh, V 2000, 'Age Differences in Technology Adoption Decisions: Implications for a Changing Workforce', Personnel Psychology, Vol. 53, No. 2, pp. 375-403.

xxxi. Nadeem, MS \& Abbas, Q 2009, 'The Impact of Work Life Conflict on Job Satisfactions of Employees in Pakistan', International Journal of Business and Management, Vol. 4, No. 5, pp. 63-83.

xxxii. Narayana, SL \& Savarimuthu, A 2014, 'Examining the relationship between work-family conflict and job satisfaction among women working in It industries inBengalura', International Journal of Conceptions in Management and Social Sciences, vol. 2, No. 2, pp. 23-26.

xxxiii. Netemeyer, RG, Brashear-Alejandro, T \& Boles, JS 2004, 'A cross-national model of jobrelated outcomes of work-role and family role variables: A retail sales context', Journal of the Academy of Marketing Science, Vol. 32, pp. 49-60.

xxxiv. Netemeyer, RG, Boles, JS \& McMurrian, R 1996, 'Development and validation of work-family conflict and family-work conflict scales', Journal of Applied Psychology, Vol. 81, pp. 400 - 410.

xxxv. Netemeyer, RG, Brashear-Alejandro, T \& Boles, JS 2004, 'A cross-national model of job-related outcomes of work role and family role variables: a retail sales context', Journal of the Academy of Marketing Science, Vol. 32, No. 1, pp. 49-60.

xxxvi. Nguyen, AN, Jim, T \& Steve, B 2003, 'Job Autonomy and Job Satisfaction: A New Evidence', Working Paper.

xxxvii. Noor, KM 2011, 'Work Life Balance and Intention to leave among academics in Malaysian Public Higher Education Institutions,' Internal Journal of Business and Social science, vol. 2, no. 11.

xxxviii. $\quad$ Opatha, HHDNP 2009, Human resource Management, Author, Colombo.

xxxix. Pasamar, S, Cabrera, RV 2013, 'Work life balance under challenging financial and economic conditions, 'International Journal of Manpower, vol. 34, no.8, pp. 961-974.

xl. Rania, S, Kamalanabhand \& Selvarania 2011, 'Work/ Life Balance Reflections on Employee Satisfaction,' Serbian Journal of Management, vol. 6, no. 11, pp. 85-96.

xli. Saif, IM, Malik, IM \& Zahid, M 2011, 'Employee Work Satisfaction and Work - Life Balance: A Pakistani Perspective', Interdisciplinary Journal of Contemporary Research in Business, Vol. 3, No. 5.

xlii. Shujat, S, Cheema, FEA \& Bhutto F 2011, 'Impact of work life balance on employee job satisfaction in Private Banking Sector in Karachi,' Journal of Management and Social Science, vol. 7, no. 2, pp. 9-15.

xliii. Thompson, CA \& David JP 2005, 'Relationship Among Organizational Family Support, Job Autonomy, Perceived Control, and Employee Well-Being', Journal of Occupational Health Psychology, Vol. 10, No. 4, pp. 100-118. 
xliv. Wang, G \& Netemeyer, R 2002, 'The Effects of Job Autonomy, Customer Demandingness, and Trait Competitiveness on Salesperson Learning, Self efficacy and Performance', Journal of The Academy of Marketing Science, Vol. 30, No.3, pp. 217-228.

xlv. Yadav, RK \& Dabhade, N 2014, 'Work Life Balance and Job Satisfaction among the Working Women of Banking and Education Sector - A Comparative study', International Letters of Social and Humanistic Sciences, vol. 10, no. 2, pp. 181-201.

Arunika, MMA

Admin Officer, Watchguard Security and Investigation (Pvt) Ltd amaliarunika85@gmail.com

\section{Kottawatta, $\mathbf{H}$}

Professor, Department of Human Resource Management, University of Sri Jayewardenepura gimhana@sjp.ac.lk 